\title{
High Court rules that Health Research Authority acted unlawfully over trial transparency
}

\author{
(C) $(1) \Theta$ OPEN ACCESS
}

\section{Clare Dyer}

The BMJ

The Health Research Authority acted unlawfully in giving "misleading" and "confusing" messages to companies carrying out early stage clinical trials about new rules on publicly registering trials, a High Court judge has ruled. ${ }^{1}$

Mr Justice Jay said that the authority's public utterances "fail the public law test of certainty and transparency," which ensures that those who are required to comply with rules can be sure of exactly what requirements they must meet.

The ruling followed a legal challenge by Richmond Pharmacology, a clinical research organisation, to the authority's transparency requirements on companies carrying out phase I trials, which test the safety and tolerability of new medicines.

The case initially involved broader issues, but it was narrowed down to an argument by Richmond that the authority was wrongly stating that companies were under a "legal" duty to register their trials on a publicly available website and to publish their results.

Although a new EU law on clinical trials is expected in 2016 the judge confirmed that no duty exists at present under EU or UK law for phase I trials to be registered on a publicly accessible website or for their results to be published. He said that the authority accepted that registration and publication were an ethical or good practice obligation rather than a strict legal duty.

The authority was legally entitled to check companies' compliance with their ethical requirement to register trials, and it was entitled to apply sanctions where ethical requirements were breached as long as the rules were clear, he added.

From 30 September 2013 the authority made trial registration and publication, including for phase I trials, a condition of approval by research ethics committees. A revised sponsor's declaration, under which companies undertook to abide by the registration and publication requirements, was introduced for all trials approved after September 2013.

From April 2015 the authority changed the sponsor's declaration to require companies to declare that all trials in active recruitment had been registered, including those approved before September 2013.
In May 2015, with Richmond bringing judicial review proceedings, the authority amended the sponsor's declaration again, removing the requirement to register trials approved before 30 September 2013. But it left virtually all of its website materials unchanged, said the judge. The website's "defective, confusing wording" fell "well short of the certainty and transparency obligations which are incidental to the rule of law" and would mislead informed readers, he added.

Janet Wisely, the authority's chief executive, said, "We will review the material identified by the judge to ensure that it is lawful." The authority will have to pay an estimated $£ 75000$ as part of Richmond's costs.

Sense About Science, the charity that runs the AllTrials campaign for clinical trial transparency, was allowed to intervene as an interested party in the case. Síle Lane, its director of campaigns, said, "The judge has clearly and comprehensively set out the legal and ethical requirements for clinical trial registration. The Health Research Authority has been given a clear mandate to continue its work raising awareness of researchers' requirements to register trials and to check researchers' compliance with those requirements.

"We're in a time of legislative change. The new EU clinical trials law is going to be adopted into UK law over the next year, so we need to be alive to the discussions that will go on during that adoption. This case has uncovered the arguments people and organisations like Richmond will be making during those discussions."

$1 \quad$ R (on the application of Richmond Pharmacology Ltd) $v$ The Health Research Authority [2015] EWHC 2238 (Admin). 28 July 2015. www.bailii.org/ew/cases/EWHC/Admin/2015/ 2238.html.

\section{Cite this as: BMJ 2015:351:h4194}

This is an Open Access article distributed in accordance with the Creative Commons Attribution Non Commercial (CC BY-NC 4.0) license, which permits others to distribute, remix, adapt, build upon this work non-commercially, and license their derivative works on different terms, provided the original work is properly cited and the use is non-commercial. See:http://creativecommons.org/licenses/by-nc/4.0/ 
Figure

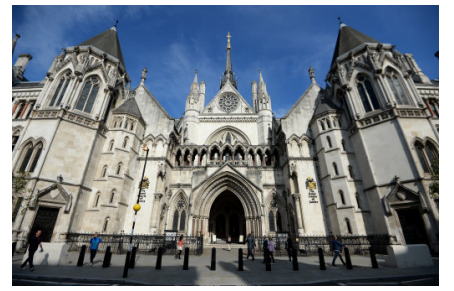

[Image: Andrew Matthews/PA Wire] 